\title{
3D Finite element model for prediction of the hot rolled strip crown and roll deformation
}

\author{
Arif Hamdam *, Mitsuhiko Sano ${ }^{\dagger}$, Masashi Tsugeno ${ }^{\dagger}$ and Kazuhiro Ohara ${ }^{\dagger}$ \\ ${ }^{*}{ }^{\dagger}$ Toshiba Mitsubishi-Electric Industrial Systems Corporation (TMEIC) \\ 3-1-1 Kyobashi, Chuo-ku, Tokyo 104-0031, Japan \\ E-mail: HAMDAM.Arif@tmeic.co.jp, Web page: http://www.tmeic.com
}

\begin{abstract}
Strip shape, which is defined by strip crown and flatness, and shape control are the most important factors in rolling product quality, production yield, and efficiency of mill operation. The shape control technology is one of the main parts of hot rolling process.

TMEIC has developed a shape setup model software to control the strip shape during online hot rolling process. In this setup model, several factors should be considered to improve shape control accuracy. Roll bending deformation, tension stress, roll profile control actuator (such as continuously variable crown (CVC) system, or pair cross system), roll thermal expansion and wear profile have big influences in the shape of rolled strip in the hot strip mill (HSM). In addition, the strip crown ratio heredity coefficient and transcription ratio coefficient are important to accurately control the hot rolled strip crown and flatness. However, it is time consuming to validate all these factors separately in actual plant. Therefore, numerical study is required to analyze some of these phenomena.

In this study, a three-dimensional Finite Element Method (FEM) for 4-High finishing rolling mill was developed to analyze the elastic-plastic deformation of strip, work roll and backup roll elastic deformation. The strip crown of different stands has been calculated and the simulation was carried out with an explicit dynamic finite element code, LS-DYNA [1]. Furthermore, the influence of work roll bending force and strip forward/backward tension on the strip crown were evaluated. From the obtained FEM results, we have calculated the strip crown ratio heredity coefficient and transcription ratio coefficient. By comparing the FEM results with the data calculated by Ogawa et. al [2], close relationships have been seen.
\end{abstract}

\section{REFERENCES}

[1] LS-DYNA, Ver. 11, http://www.lstc.com/products/ls-dyna.

[2] S. Ogawa, H. Matsumoto, S. Hamauzu and T. Kikuma, "On-line calculation method of strip crown in hot strip mills", Journal of the Japan Society for Tech. of Plasticity, Vol. 25, No. 286, 10341041 (1984) (in Japanese). 